Personalidade Acadêmica Homenageada:

Florisbal de Souza Del'Olmo (Professor Convidado - UNICURITIBA)

\title{
PONDERAÇÃO DE DIREITOS FUNDAMENTAIS: UMA FORMA PARA RESOLUÇÃO DE CONFLITO NORMATIVO NO CASO CONCRETO RELACIONADO AO ABORTO
}

VIVIANE DUARTE COUTO DE CRISTO

Mestre em Direito pelo Centro Universitário Curitiba - UNICURITIBA; Pós Graduação Lato sensu em Administração Pública pela UniBrasil; Graduação em Direito pela Faculdade de Direito de Curitiba (FDC); Professora no Curso de Direito da Faculdade Nacional de Educação e Ensino Superior do Paraná - FANEESP, nas disciplinas de direito civil e direito administrativo; Mediadora Judicial TJ-PR (em fase de estágio supervisionado no CEJUSC Cível de Curitiba); Pesquisadora do Grupo de Pesquisa Direito Empresarial e Cidadania no Século XXI do Centro Universitário de Curitiba - UNICURITIBA; Secretária da Comissão de Gestão Pública, Transparência e Controle da Administração da OAB-PR; Procuradora Geral do Município de Campina Grande do Sul-PR (2005-2008); Assessora Parlamentar da Assembléia Legislativa do Paraná (2002-2004). Advogada. Áreas de pesquisa: métodos consensuais de resolução de conflitos, mediação, acordo de leniência, acesso à informação pública, transparência, controle da Administração Pública, combate à corrupção, governança e compliance.

CLEIDINEIA MARIANO DA SILVA Graduada em Técnico em Meio Ambiente pelo Colégio João Paulo II (2012) e ensinomédio-segundo-graupelo COLEGIO ESTADUAL GUIDO STRAUBE (2009). 


\section{Personalidade Acadêmica Homenageada:}

Florisbal de Souza Del'Olmo (Professor Convidado - UNICURITIBA)

\section{RESUMO}

Este estudo trata do conflito entre dois direitos fundamentais de ordem constitucional, o direito à vida do nascituro e o direito à liberdade e autonomia da mulher, e consiste na tentativa de uma resolução a esta problemática, com base na teoria de Ronald Myles Doworkin.

\section{INTRODUÇÃO}

Esta pesquisa objetiva apresentar 0 choque entre dois direitos fundamentais, o direito à vida do nascituro versus o direito à liberdade da mulher. Esta discussão polêmica voltou à tona recentemente com o julgamento da Arguição de Descumprimento de Preceito Fundamental (ADPF) № 442 pelo STF, ainda em fase de julgamento após a realização de audiência pública com a manifestação de inúmeros setores da sociedade em posições a favor e contra a interrupção da gestação até o décimo segunda semana de gestação. O HC 124.306-RJ, da $1^{\text {a }}$ Turma do STF, sob relatoria do Ministro Luís Roberto Barroso, decidiu em um caso concreto que o aborto até a décima segunda semana de gestação não se configura como crime de aborto. A intenção da pesquisa é provocar o debate acadêmico de tema tão relevante e oportuno, avaliando a possibilidade de aplicação da teoria de Ronald Myles Dworkin na ponderação destes direitos protegidos pela Constituição Cidadã.

\section{PROBLEMA DE PESQUISA}

Em que medida é possível a resolução de uma situação de conflito entre direitos fundamentais previstos na Constituição Federal de 1988, sendo eles o direito à vida e o direito à liberdade da mulher, com base na ponderação defendida por Ronald Doworkin? 


\section{Personalidade Acadêmica Homenageada:}

Florisbal de Souza Del'Olmo (Professor Convidado - UNICURITIBA)

\section{OBJETIVO}

O objetivo do presente trabalho é realizar a ponderação de dois direitos fundamentais, o direito à vida e o direito à liberdade da mulher, tendo como base a teoria de regras e princípios de Ronald Myles Dworkin.

\section{MÉTODO}

A pesquisa ainda em fase inicial de realização, desenvolveu-se através do método dedutivo, mediante revisão bibliográfica em livros e artigos científicos relacionados aos assuntos tratados.

\section{DESENVOLVIMENTO}

A Declaração Universal dos Direitos Humanos (1948), criada com fundamento no princípio da dignidade da pessoa humana inspirou as Constituições de inúmeros países, incluindo o Brasil. $\mathrm{O}$ art. $5^{\circ}$ da Constituição Federal de 1988 consagra os Direitos Fundamentais também com alicerce no princípio da dignidade da pessoa humana. Tais direitos possuem um elevado conteúdo axiológico, e sobrepõe-se a qualquer outro direito. O problema consiste quando há choque entre direitos fundamentais, como é o caso do direito à vida do nascituro em contraposição ao direito de liberdade da mulher.

A teoria de Dworkin pode ser útil na resolução de tal conflito, pois ela baseiase na distinção de princípios e regras, salienta que as regras possuem uma dimensão de validade, são aplicadas à maneira do tudo-ou-nada. Porém, os princípios possuem dimensão de peso ou importância, e como os direitos fundamentais decorrem destes princípios, entende-se válida nas hipóteses de conflitos desta natureza. Quando estes entram em colisão o direito com maior 


\section{Personalidade Acadêmica Homenageada:}

Florisbal de Souza Del'Olmo (Professor Convidado - UNICURITIBA)

relevância prevalece sobre o outro, no entanto, o outro direito não deixa de ser válido, ele apenas não possui um peso maior para prevalecer em um determinado caso.

O caso concreto com as suas peculiaridades pode trazer soluções diversas, ora aplicando-se um princípio, ora outro. Tanto que a legislação brasileira prevê especificamente a possibilidade do aborto quando há risco à vida da mulher e gravidez resultante de estupro, e o Supremo Tribunal Superior já decidiu sobre a possibilidade do aborto de feto anencefálico. Porém, a interrupção antecipada da gravidez é considerada crime, por encontrar-se tipificada nos artigos 124,125 e 126 do Código Penal, e seu cometimento significaria necessária subsunção à norma, alterável apenas com modificação legislativa.

\section{RESULTADOS ALCANÇADOS}

Após análises e leituras de diversas teorias, conclui-se que a teoria do sopesamento dos princípios de Dworkin é de suma importância para a resolução de conflito entre direitos fundamentais, que decorrem imediatamente dos princípios constitucionais avaliando-se as peculiaridades de cada caso concreto. Todavia, mesmo abstratamente, quando não se tratar de hipóteses legais, é possível considerar no sopesamento entre $\mathrm{o}$ direito à vida e o direito à autonomia e à liberdade, que o direito à vida se coloca como um peso de maior relevância, especialmente na valoração do direito brasileiro decorrente do Processo Legislativo, sendo este direito uma essência, e a partir dele que decorreriam os demais.

\section{REFERÊNCIAS}

MIRABETE, Julio Fabbrini; N. FABBRINI Renato. Manual de Direito Penal. Vol. 3, $28^{\circ}$ Edição Revista e Atualizada até janeiro de 2011, pg. 57-66. São Paulo, editora Atlas S.A. -2011. 
Personalidade Acadêmica Homenageada:

Florisbal de Souza Del'Olmo (Professor Convidado - UNICURITIBA)

MOREIRA, Daniel Camurça; BOTELHO, Carla Mariana Café. O aborto e a personalidade jurídica do nascituro: uma crítica feminista ao ordenamento jurídico brasileiro. Caderno Espaço Feminino - Uberlândia-MG - v. 30, n. 1 - Jan./Jun. 2017 - ISSN online 1981-3082.

PAMPLONA FILHO, Rodolfo; ARAÚJO, Ana Thereza Meirelles. Tutela jurídica do nascituro à luz da Constituição Federal. Rev. Magister de Direito Civil e Processual Civil, Porto Alegre, v. 3, n. 18, p. 33-48, maio/jun. 2007.

SILVA, Virgilio Afonso da. Principios e regras. Revista Latino-Americana de Estudos Constitucionais 1 (2003): pg. 607-630.

SILVA, Virgilio Afonso da. O conteúdo essencial dos direitos fundamentais e a eficácia das normas constitucionais. Revista de Direito do Estado 4 (2006): pg. 2351. 